\title{
Shallow Discussion of Higher Vocational College Students' Legal Quality of Ascension
}

\author{
Xiaozhen zhang \\ Hebei Vocational \& Technical College of Building Materials, Qin huang dao city wenyu road No.8, Hebei Province, China \\ Xiaozhen zhang@021223@163.com
}

\begin{abstract}
The legal quality is an important part of college students' comprehensive quality, is indispensable to modern rule of law society on college students' quality of internal requirement. At present, the higher vocational college students' legal quality is low, which can't meet the needs of its usage and obey the law, and, from a certain extent, which also affect the process of social legal system construction. Facing the status of legal quality of the higher vocational college students, To actively explore the countermeasure of students' legal quality promotion is the eternal subject of higher vocational education workers need to study.
\end{abstract}

Index Terms - higher vocational college students Legal quality Improve countermeasures

\section{Introduction}

With China's higher vocational education development, Higher vocational college students has become a country's main source of high-quality skilled personnel. The cultivation of higher vocational college students' comprehensive qualities will have a major impact for a region , a province and even the whole country. Legal quality is an important part of college students' comprehensive quality, Improving the quality of the higher vocational college students' legal is the important content of personnel training goals. At present, higher vocational college students' legal quality education has obtained certain achievements, But due to various reasons, Higher vocational students' legal quality is still low, How to improve higher vocational students' legal quality is an important subject worth exploring.

\section{The Meaning of Legal Quality}

Legal quality is about the method and the phenomenon of a variety of legal knowledge, understanding, ideas, consciousness, ideology, psychology and ability to put together. It mainly displays in the understanding of the law itself, and attitude to the requirements of current laws, attitude to the requirement of the current law, evaluation and understanding the law of running state, the evaluation of legal behavior, law-abiding and usage ability and so on. Legal knowledge, legal consciousness, legal practice is the three basic elements of legal quality, the three is mutual promotion, complementary to each other. Among them, the legal knowledge is the foundation of the formation of legal quality, to improve the quality of the law, must have a systematic, comprehensive, rich legal knowledge. And legal consciousness is the understanding of various legal phenomena, opinions and the floorboard of the psychological, is the idea base of the formation of legal quality. The legal practice is the basis of forming legal practice quality, Legal application and practice ability is the proper legal requirements of quality, but also promote the formation of the modern legal quality practice conditions.

\section{The Status of Legal Quality of College Students}

The legal quality of vocational college students is the sum of the basic ability and the level they have legal knowledge, legal consciousness, and apply the law. Legal quality is the internal requirement for the rule of law in modern society the indispensable for citizens, especially for college students. With the continuous development of our construction of rule of law, the legal quality of college students have made some progress, but it is not optimistic. In recent years, college students crime incidents happened frequently proves that the legal quality of college students is still low on the whole. To sum up, mainly manifested in the following aspects:

1) Lack of legal knowledge. Legal knowledge is the foundation of legal quality, In recent years, Due to continuously strengthen and improving ideological and political education, the higher vocational colleges students legal knowledge has increased, but only stay on the level of perceptual knowledge, and there is a big gap between "knowledge" and "action". As a whole Legal knowledge is not high, the knowledge structure is imperfect. The quality of higher vocational education students is declining, their ability to master the basic knowledge of law is generally lower, and the lack of learning and exploring interest. At the same time, Higher vocational colleges pay attention to skills and despise theory teaching reform, The influence of utilitarianism in directly led to the students' learning focusing on learning professional skills and lack of interest in some basic courses. Many students only like to listen to case analysis, are not interested in strong theoretical knowledge of law. In fact, the legal theory knowledge is the basis of the practical legal knowledge.

2) The legal consciousness is not strong. This is prevalent in today's college students status. On the one hand, the phenomenon of student population crime is increasing, on the other hand, when their own legitimate rights and interests are infringed upon, they don't know how to use legal weapon to safeguard their rights. Such as: In 2004 February Yunnan University student Jiajue Ma hammer to kill the dormitory four students; in 2008 October, China University of Political Science and Law students for emotional entanglements to kill teacher; in 2009 April, at a university in Shanxi ,Junior Chen continuously in the school to steal bicycles and notebook 
computer. Survey showed that: vocational college students most agree that "any organization or individual shall be beyond the constitutional and legal privileges" point of view, but also agreed that in real life "right above the law" phenomenon often occurs. In addition, higher vocational college students know that some of the relevant legal obligations, such as pay taxes according to law, military service law, but little about the rights endowed by laws known.

3) Low legal practice ability. Higher Vocational College Students' legal practice refers to the ability of its formation in learning knowledge of law and the rule of law in practice of long-term, to use the law to regulate and guide the behavior, to resolving conflicts, to safeguard their legitimate rights and interests, to investigate illegal behavior. The current higher vocational college students' legal quality is generally not high, do not have general legal practice ability, the main reason, on one hand, is that "the supremacy of law" concept did not win support among the people, on the other hand is the knowledge of structural constraints. In the understanding of the legal questions, most of vocational college students can only understand some simple questions of law, not in-depth analysis of the legal issues more complex. In the daily practice of law, is the practice ability level is low, not only has appeared in this group of criminal acts, but also in their usage ability is weak, not good at the law applied to our daily life.

\section{Method to Improve the Legal Quality of College Students of Higher Vocational Education}

1) Focus on higher vocational college students' legal quality education. College students' legal quality enhancement in a legal quality education occupies an extremely important position, Therefore, we must attach great importance to it, And put it as the most important work to grasp for the legal quality education. At present, most vocational college students legal education is generally carried out by the organization form of classroom teaching or legal lecture, limited human, material and financial resources to meet the professional construction, professional knowledge and professional skills training, College students' legal quality improvement in the training process has not received sufficient attention. Higher vocational colleges should take improving the legal quality of college students effectively incorporated into the target of personnel training, must transform the education teaching thought, a profound understanding of the significance of improving the legal quality of College students. University is not only to strengthen the training of professional knowledge, but also should pay attention to the cultivation of legal quality, and takes it as an important content to enhance the overall quality of students, enhance the legal consciousness, so that to develop good habits of the law. At the same time, The university should strengthen the intervention mechanism of College Students' mental health education and crisis to prevent the extreme thoughts of students effectively, make them get rid of the spiritual dilemma to avoid illegal events and promote their healthy development of body and mind.

2) The building of a harmonious campus environment for the rule of law. The environment affects people, educate people and train people. A good campus environment for the rule of law will make the cultivation of legal quality of vocational college students have a multiplier effect. In the rule of law environment, higher vocational colleges must adhere to the rule of law, strictly abide by the "Higher Education Act" occupation ,"Education Law" ,"Teachers Law" ,"ordinary college student management regulations" and other laws and regulations, University should regulate and management behavior, between schools and teachers, the school and students and teacher-student relationship of rights and obligations, and strive to create a good campus environment for the rule of law. When the dispute between teachers and students, between students and school, university should act according to law, let students experience the equity of the law. At the same time, we must strive to overcome the officialdom standard thought and pan administrative phenomenon in the school management. In addition, the school should make full use of the campus net, bulletin boards and broadcast the position of public opinion, to construct the campus learning method, the law, law-abiding atmosphere.

3) Strengthening the effectiveness of the teaching of the basic course of law. University should be popularize basic knowledge of law by higher vocational colleges "Ideological and political education and law basis" course platform, strengthen the reform in teaching methods, teaching means. According to the characteristics of higher vocational college students' ability of reception theory is poorer, the university may adopt the following teaching methods: one is the case teaching method which is the basic legal principle into one or a few cases, through the analysis of case anatomy, make the students master the basic theory, familiar with the law. But should pay attention to the selected case should be real, typical, rigorous, especially to occur in the case of the students around, and the case should also be educational, vivid and comprehensive. Second, the method of class discussion. Students can be grouped in form, but also the whole class discussion, both to exercise in higher vocational college students' ability to analyze and solve problems, and to inspire the enthusiasm of research method usage; Students are encouraged to speak up, published his views and opinions, and then the teacher evaluation and analysis of cases, both to consolidate knowledge, and can exercise their own thinking and eloquence. Three is to organize the moot court. Teachers choose the typical cases in or around the school, the students were divided into different groups, acting out different roles, the classmates trial case in strict accordance with the procedure, the last teachers evaluate students' performance. Four is to give full play to the advantages of multimedia teaching means. Multimedia teaching is not only material, a large amount of information, illustrated, easy to enable students to acquire perceptual knowledge of legal principle, and the form of vivid, can arouse the students' interest in learning, active classroom atmosphere, changed teaching 
mode of from the "point" to "view", from "theory" to the "theory" .

4) Expand new ways to cultivation of legal quality

In addition to the University Ideological and political theory course teaching is the main channel of vocational college students legal quality cultivation, should also be other ways to actively expand the legal education. To carry out various forms of legal education activities, creating a strong campus culture environment, so that students can be subjected to the influence of legal knowledge, and gradually establish legal awareness. Such as the organization of campus legal knowledge contest; organize regular watch "today", "law and society", "legal forum" and other legal program; organization legal practitioners, law enforcement and judicial personnel to carry out the legal knowledge lectures; guide students in holidays to carry out social surveys and the theme of social practice activities, including social security cases, land contract marriage and family disputes, contradictions, the implementation of the compulsory education, college students violation of law, consumer protection law and other related issues. The teacher often organize the students to discuss life frequent case, If conditions allow, can also organize students to participate in the courtroom, make the students feel the court solemn atmosphere, feel the sacred and the dignity of law, improve the students' legal quality to inspire and influent college students through a variety of ways .

\section{References}

[1] Xiaohua Zhang. The legal quality of college students in higher vocational colleges training approach. Journal of Harbin Vocational and Technical College, 2007 (3)

[2] Zhonggu Huang i. On the legal qualities of vocational students to enhance. education and occupation, 2010 (27)

[3] Qiuyan, Zheng Yan Xie, Wang Xu. The legal consciousness of Higher Vocational College Students in the new period culture transit. theory study, 2009 (2)

[4] Yunxia Huang. Study on the problems and Countermeasures of university legal education, education theory and practice, 2007 (3) 